Yayın Geliş Tarihi: $\quad 28.06 .2016$

Yayın Kabul Tarihi: 28.04 .2017

Online Yayın Tarihi: 04.12.2017
Dokuz Eylül Üniversitesi İktisadi ve İdari Bilimler Fakültesi Dergisi Cilt:32, Sayl:2, Yll:2017, ss. 79-107

\title{
Turizm Gelirleri ve Dışa Açıklık Arasındaki İlişki: Türkiye Örneği
}

\section{Harun TERZi $\mathbf{I}^{1}$}

\author{
Asiye TÜTÜNCÜ²
}

\begin{abstract}
$\ddot{O} z$
Bu çalışmada, turizm gelirleri ve dışa açıkllk arasındaki ilişki 1985-2014 dönemi ylllk veri seti ile $S$-VAR, TY-VAR ve DL-VAR nedensellik yöntemleriyle incelenmiştir. $V A R$ nedensellik analizleri, dı̧sa açılklktan turizm gelirlerine doğru pozitif ve istatistiksel olarak anlaml bir nedensellik ilişkisi olduğunu göstermektedir. Aynı zamanda VAR analizlerinden elde edilen geliştirilmiş etki-tepki ve geliş̧tirilmiş varyans ayrış̧tırma analizleri de VAR nedensellik sonuçlarını desteklemektedir. Sonuç olarak, Türkiye'de dıș ticarette serbestleşme ve ticari açıklık arttıkça uluslararası turizm gelirleri de artmaktadir.
\end{abstract}

Anahtar Kelimeler: Turizm Gelirleri, Dışa Açıklık, S-VAR, TY-VAR, DL-VAR.

JEL Sintflandirma Kodlart: L83, F14, C51.

\section{The Relationship between Tourism Revenues and Trade Openness in Turkey}

\begin{abstract}
In this study is examined the relationship between tourism revenues and trade openness in Turkey with annual data for the period of 1985-2014 by using the S-VAR, TY-VAR and DL-VAR causality methods. The VAR causality analyses show that there is a positive one-way causality running from trade openness to tourism revenues. Additionally, the findings of generalized impulse-response functions and generalized variance decomposition analyses also support the results of the VAR causality results. As a result, as long as foreign trade liberalization-openness in Turkey increases, positively encourage international tourism revenues as well.
\end{abstract}

Keywords: Tourism Revenues, Trade Openness, S-VAR, TY-VAR, DL-VAR, Turkey.

JEL Classification Codes: L83, F14, C51.

${ }^{1}$ Prof.Dr., Karadeniz Teknik Üniversitesi, İktisadi ve İdari Bilimler Fakültesi, İktisat Bölümü, hterzi@ktu.edu.tr

${ }^{2}$ Araş.Gör., Karadeniz Teknik Üniversitesi, Sosyal Bilimler Enstitüsü, Ekonometri Bölümü, asiyetutuncu@ktu.edu.tr 


\section{Gíriş}

\section{H.TERZİ -A.TÜTÜNCÜ}

İş seyahatleri, başka bir ülkeye bir şey satmak ya da başka bir ülkeden bir şey almak için gerçekleştirilen seyahatler olarak tanımlanır. Başarılı iş seyahatleri ithalat ve ihracat akışına izin verir; böylelikle daha fazla iş seyahati için firsat oluşturulur. Artan iş seyahatleri ise, arkadaş veya akrabalarla daha sonradan tatil, macera veya dinlenme gibi diğer seyahat türlerine dönüşebilmektedir. Bunun yanı sıra, başka bir ülkeden gelen ürünler, ürünün üretildiği kaynak ülkeyle gerçekleştirilen seyahatlerin de artışına neden olabilir. $\mathrm{Bu}$ ilgi ve farkındalık tatil seyahatlerini arttırabilir. Uluslararası ticaret akımını arttıran ve böylece ticari faaliyetlerinde daha açı hale gelen ülkeler, aynı zamanda uluslararası turist sayısını da arttırmaktadır (Kulendran ve Wilson, 2000: 1001-1002). Bu nedenle turizm ve dışa açıklık arasındaki ilişkinin varlı̆̆ 1 ve yönünü belirlemek son derecede önemlidir.

$\mathrm{Bu}$ çalışmanın amacı, turizm gelirleri ile dışa açıklık arasındaki ilişkinin analizidir. Çalışma altı bölümden oluşmaktadır. Giriş bölümünü takip eden ikinci bölümde uluslararası turizm ve uluslararası ticaret arasındaki ilişki ele alınmıştır. Ardından Türkiye'de uluslararası turizm ve uluslararası ticarete değinilmiştir. Üçüncü bölümde konuyla ilgili literatür taramasına yer verilmiştir. Dördüncü bölümde ekonometrik yöntemden, beşinci bölümde ise veri seti ve bulgulardan bahsedilmiştir. Sonuç bölümde ise, elde edilen bulgular özetlenerek değerlendirilmiştir.

\section{ULUSLARARASI TURIZM VE ULUSLARARASI TİCARET}

Bireylerin eğlence, iş ve diğer amaçlarla kendi çevrelerinden farklı bir yerde bir yılı geçmeyen kalma veya seyahat faaliyetleri olarak tanımlanan turizm (World Bank, 2014: 93), ikinci dünya savaşından sonra ülkeler arasında hızla gelişmeye başlamıştır. Ülkelerin gelişmişlik durumları ne olursa olsun turizm faaliyetleri, ülkenin ekonomik verilerini ve politikalarını etkilemektedir. Çünkü turizmden, ulusal ve uluslararası düzeyde elde edilen gelir, yatırımları ve dolayısıyla istihdamı arttırmaktadır. Bunun yanı sıra turizm gelirleri, gelir 
yaratan ve ülkeye döviz akışını sağlayan bir faktördür (Bulut, 2000: 71). Literatürde yapılan çalışmalar, uluslararası turizmin ekonomik göstergeler üzerinde çok sayıda etkisinin olduğunu göstermektedir.

Ayrıca World Tourism Organization (WTO)'nun yaptığı çalışmalarda, turizmde meydana gelen büyüme hızının diğer ekonomik göstergelerde meydana gelen büyüme hızından daha fazla olduğu gözlenmektedir.

Dışa açılık derecesi yüksek olan ülkeler, turizm de dahil olmak üzere uluslararası mal ve hizmet sektörlerindeki pazar erişimlerini artırabilmektedirler. Ayrıca yurt içi yurt dışı firmaların ticari faaliyetlerinin dışa açıklık üzerinde etkisinin olduğu görülmektedir.

Dışa açıklığın, turizmi teşvik etme eğilimine sahip olması beklenmektedir; çünkü ülkelerin uluslararası ticarete açılması sadece turizm sektörünün kendisi ve uluslararası turizme teşvik için pazar erişimi sağlamamaktadır.

Aynı zamanda bu durum mal ve hizmet piyasasında rekabeti artırmaktadır. Böylece, turistler daha ucuz mal ve hizmetin yanı sıra daha fazla çeşitlilikle daha iyi bir tatil imkanına sahip olabilmektedirler (Wong ve Tang,2008: 56).Khan (2006)'a göre 'turizm ve ticaret arasında ilişki şu şekildedir (Fry, Saayman ve Saayman, 2010: 287):

(1) Turistler kendi ülkelerinden başka bir ülkeye gittiklerinde harcamaları da kendi ülkelerinden diğer ülkeye doğru kaymaktadır. Böylelikle turizm ticarete neden olmaktadır;

(2) Seyahatler aynı zamanda uluslararası ticareti arttırır. İş seyahatleri aracılığıyla yapılan ticari anlaşmalar, yeni girişimleri ya da hükümetlerin yetkilileri sayesinde uluslararası ticareti arttırmaktadır;

(3) Turistler lüks eşyalar almak için veya yerel ürünlere olan taleplerinden dolayı da seyahat etme eğilimine sahip olabilirler. 


\section{H.TERZİ -A.TÜTÜNCÜ \\ 2.1. Türkiye'de Uluslararası Turizm ve Uluslararası Ticaret}

Turizm son yüzyılın önemli ekonomik ve sosyal olaylarından biridir ve şüphesiz, gelecek yüzyıllar boyunca da bu durum devam edecektir. Her y1l dünya nüfusunun büyük bir bölümü turizm aktivitelerinde bulunmakta ve ülkelerin çoğunda turizm ekonominin en dinamik ve en hılı büyüyen sektörleri arasında yer almaktadır (Luzzi ve Flückiger, 2003: 239). Türkiye'de turizme yönelik politikalar 1980'li yıllarda belirlemeye başlamıştır. Turizm sektörünün gelişimini hızlandırmak için “Turizm Teşvik Yasası” 1982 yılında yürürlüğe girerken, 1985 yılında turizm, "Kalkınmada Özel Önem Taşıyan Sektörler” arasına alınmıştır. Böylelikle turizm sektörünün önündeki engeller kaldırılarak, turizmin, Türkiye ekonomisi için önemli bir sektör haline gelmesi sağlanmıştır (Zengin, 2010: 106).

Dünya ekonomisi içerisinde gözlenen turizmdeki büyüme Türkiye ekonomisi içinde geçerlidir. Şekil 1'de görüldüğü üzere, Türkiye'nin turizm gelirleri ve turist sayısı bakımından son yıllarda dünyada ilk 10 ülke içerisinde yer aldığı görülmektedir. Ülkemize gelen turist sayısında özellikle 2007 yılından itibaren belirgin bir şekilde artış yaşanırken, elde edilen turizm gelirlerindeki etkisini daha erken dönemlerde, 2003 yılından itibaren göstermektedir. Türkiye'de 1982 yılında Turizm Teşvik Kanunu ile başlatılan turizm yatırımlarına yönelik çalışmalarının 2000'li yıllarda artış gösterdiği görülmektedir. Turizm gelirleri dikkate alındığında ilk on ülke arasında bulunan Türkiye, turizmde söz sahibi ülkeler arasında yer almaktadır. Bunun yanı sıra, turist sayısında da 2006 yılı hariç diğer dönemlerde bir önceki döneme göre ilerleme yaşanmıştır. 2005 yılının son dönemlerinde Türkiye'de ortaya çıkan kuş gribi vakaları, 2005-2006 döneminde dış basında konuyla ilgili olumsuz haberlerin yayınlanmasına neden olmuştur. Ayrıca aynı dönemde İran'da artan gerginlik ve yaşanan Irak savaşı, Türkiye'nin güven ortamından yoksun olduğu algısına sebep olmuş, turizm faaliyetlerin azalmasıyla sonuçlanmıştır. Tüm bu olumsuz gelişmeler 2006 yılında turizm faaliyetlerinde azalma yaşanmasına neden olsa da, alınan tedbirlerle sonraki dönemlerde iyileşme yaşanmıştır. 


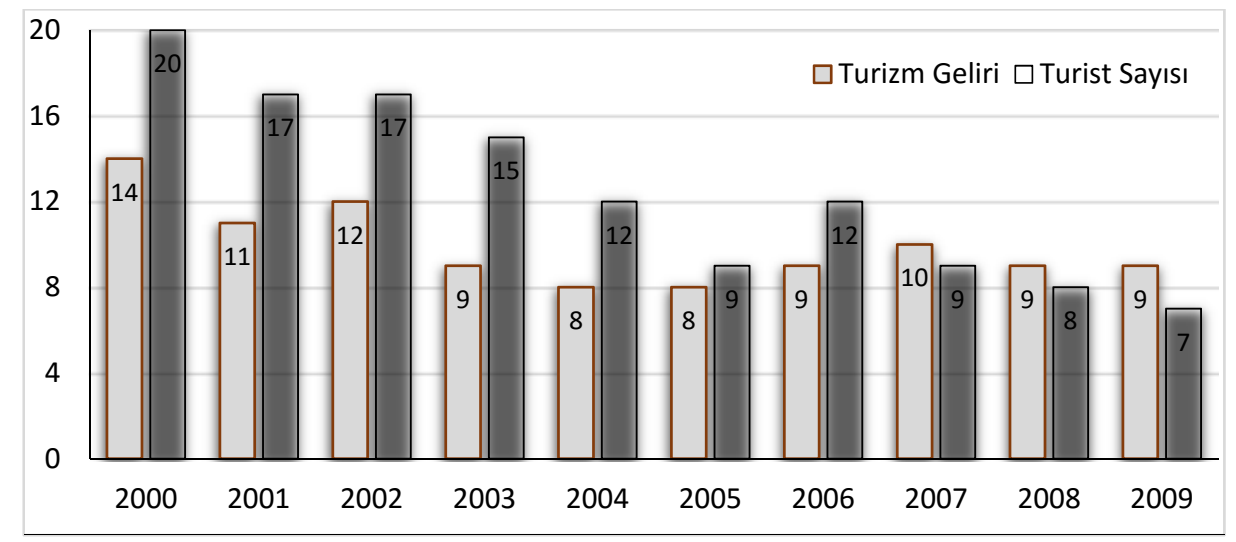

Şekil 1. Türkiye'nin Turist Sayısı ve Turizm Gelirlerindeki Dünya Sıralaması

Kaynak: T.C. Kültür ve Turizm Bakanlığı, 2016.

Bir hizmet sektörü olan turizm, üretilen mal ve hizmetlerin üretildikleri yerde tüketilmelerini sağlamaktadır. Böylelikle üretilen mal (yiyecek, içecek, hediyelik eşya vb ve hizmetler, üreticilerine yurtdışına herhangi bir mal ve hizmet göndermeksizin döviz geliri elde etme imkanı sağlamaktadır. Bir bakıma turistler tarafından satın alınan mal ve hizmetler döviz gelirlerini arttırarak ülkenin ihracat kalemine pozitif olarak yansımaktadır (Zengin, 2010: 105).

Dünyada gerçekleştirilen hizmet ticaretinin yaklaşık \%40’1 turizm sektöründen meydana gelmektedir. Bu nedenle turizm uluslararası ticarette en önemli kalemlerinden biridir. Ayrıca turizm sektörü ekonomik gelişimde ihracat kalemine önemli katkı sağlamaktadır (Bahar ve Bozkurt, 2010: 256). Şekil 2'de yer alan Türkiye'de milliyetlerine göre ülkeye giriş yapan turistlere ait 2013 y1lı ve 2014 y1lı verileri incelendiğine, ülkeye en çok turist gönderen 15 ülkeden 9’u aynı zamanda en çok ihracat yapılan ilk 15 ülke içerisinde yer almaktadır. Diğer 6 ülkeden Belçika 2013 yılında 19. sırada yer alırken 2014 y1lına 17. sırada yer almaktadır. Gürcistan, Bulgaristan, Ukrayna, İsveç ve Yunanistan ise her iki yılda da Türkiye'nin en çok ihracat yaptığı ilk 30 ülke içerisindedir. 


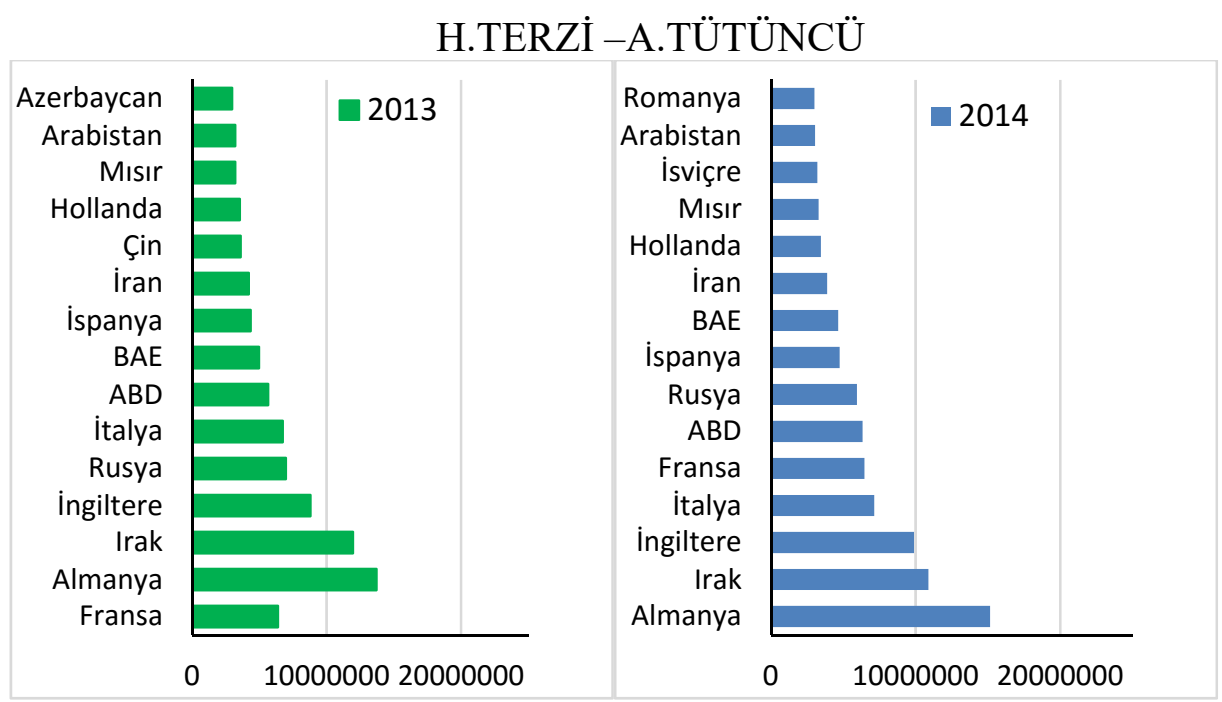

Şekil 2. İhracat (İlk 15 Ülke, Bin Dolar)

Kaynak: T.C. Gümrük ve Ticaret Bakanlığı, 2016.

Diğer yandan, Türkiye'den diğer ülkelere giden turistler gittikleri ülkede turistik mal ve hizmet ithalatına yönelik yaptıkları harcamalarla döviz talebini arttırarak ithalat kalemine katkı sağlamaktadır. Her ne kadar Türkiye'ye gelen turistler yöresel tatları deneseler de kendi kültürlerine ait yiyecek ve içecekleri de tüketmek istemektedirler. $\mathrm{Bu}$ nedenle yiyecek ve içecek sektörüne ait ürünlerde ithalata konu olmaktadır. Aynı zamanda konaklama sektörü ve donanım hizmetlerinde gerekli olan malzemelerin önemli bir bölümü de ithal edilmektedir (Egeli, 1997: 235). Şekil 3'de yer alan 2013 ve 2014 y1lına ait Türkiye'nin ithalat faaliyetlerini gerçekleştirdiği ilk 15 ülke incelendiğinde, 2013 y1lında 8; 2014 yılında ise 9 ülke milliyetlere göre gelen turist sıralamasındaki ilk 15 ülke içerisinde yer almaktadır. Bunlardan Gürcistan ve Irak hariç diğer ülkeler ise her iki yılda da Türkiye'nin ithalat yaptığı ilk 30 ülke içerisindedir. 


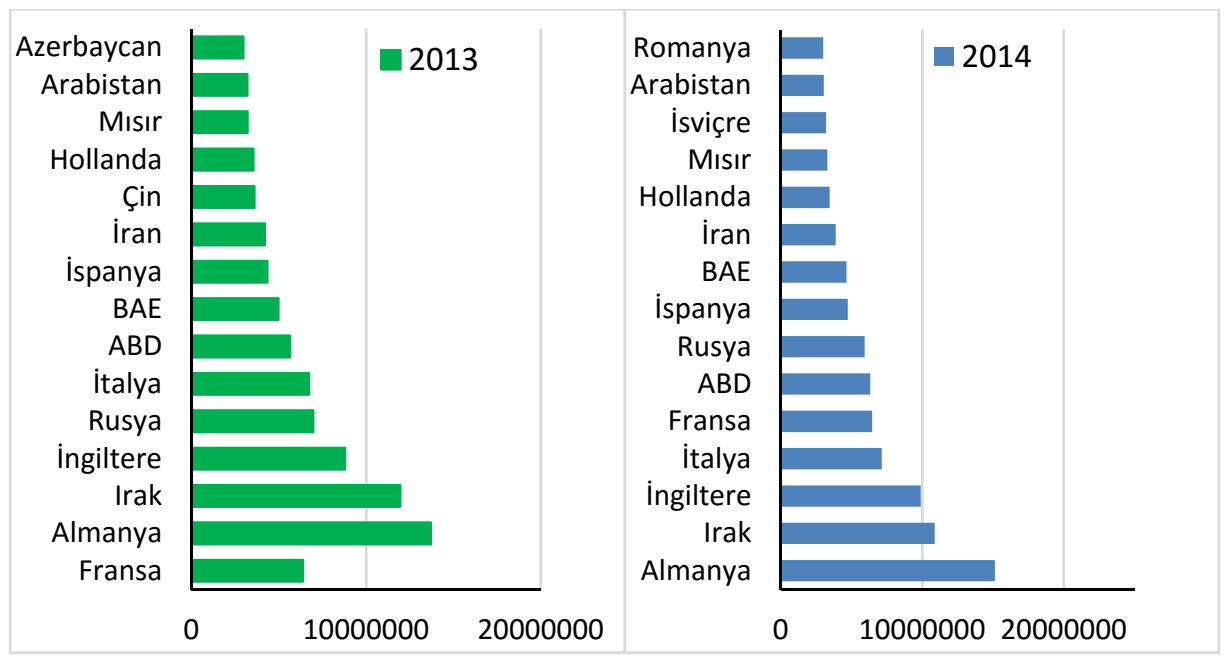

Şekil 3. İthalat (İlk 15 Ülke, Bin Dolar)

Kaynak: T.C. Gümrük ve Ticaret Bakanlığı, 2016.

T.C. Gümrük ve Ticaret Bakanlığı verilerine göre, Türkiye'nin ithalat yaptığ1 ilk 5 ülkenin gelişmiş ülkeler olduğu görülmektedir. Türkiye gibi gelişmekte olan ülkelerde bu durum şaşırtıcı değildir çünkü bu ülkeler üretimlerinde ithal malları girdi olarak kullanmaktadır (Telatar ve Terzi, 2009: 119).Tablo 1'de Türkiye'ye en çok turist gönderen 15 ülkenin, Türkiye ile gerçekleştirdikleri ithalat ve ihracat faaliyetlerinde kaçıncı sırada oldukları gösterilmektedir. Almanya en çok turizm faaliyetlerinde bulunduğumuz ülke olmasının yanı sıra, Türkiye ile en çok ihracat faaliyeti gerçekleştirilen ülkedir. Almanya'da yaşan Türkiye vatandaşı sayısının oldukça yüksek olması bu durumun en önemli nedenlerindendir. Ailelerini ziyarete gelen bireyler turist sayısının, ülkelerinde var olan ürünleri Almanya'da da temin etme istediği de ihracat kaleminin artmasına katkı sağlayabilir. Turizm ilişkilerinin en yoğun olduğu ilk 15 ülkeden dış ticaret faaliyetleri genellikle gelişmiş ülkelerle gerçekleşmiştir. Irak ise, en çok ihracat yapılan 2. ülke olmasına rağmen ithalat faaliyetlerinde oldukça geridedir. 


\section{H.TERZİ -A.TÜTÜNCÜ}

Tablo 1. Türkiye'ye En Çok Turist Gönderen 15 Ülkenin İhracat ve İthalattaki Siralaması

\begin{tabular}{|c|c|c|c|c|c|c|}
\hline & \multicolumn{2}{|c|}{ Turizm } & \multicolumn{2}{|c|}{ İhracat } & \multicolumn{2}{|c|}{ İthalat } \\
\hline Ülkeler & 2013 & 2014 & 2013 & 2014 & 2013 & 2014 \\
\hline Almanya & 1 & 1 & 1 & 1 & 3 & 3 \\
\hline Rusya Fed. & 2 & 2 & 4 & 7 & 1 & 1 \\
\hline İngiltere & 3 & 3 & 3 & 3 & 12 & 12 \\
\hline Gürcistan & 4 & 4 & 26 & 28 & 70 & 69 \\
\hline Bulgaristan & 5 & 5 & 23 & 24 & 22 & 23 \\
\hline İran & 7 & 6 & 10 & 10 & 7 & 7 \\
\hline Hollanda & 6 & 7 & 12 & 11 & 20 & 17 \\
\hline Fransa & 8 & 8 & 6 & 5 & 9 & 8 \\
\hline Irak & 12 & 9 & 2 & 2 & 81 & 65 \\
\hline Ukrayna & 10 & 10 & 20 & 26 & 15 & 14 \\
\hline A.B.D. & 9 & 11 & 7 & 6 & 6 & 4 \\
\hline İtalya & 11 & 12 & 5 & 4 & 5 & 6 \\
\hline İsveç & 14 & 13 & 28 & 30 & 25 & 27 \\
\hline Belçika & 15 & 14 & 19 & 17 & 17 & 16 \\
\hline Yunanistan & 13 & 15 & 25 & 27 & 16 & 15 \\
\hline
\end{tabular}

Kaynak: T.C. Kültür ve Turizm Bakanlığı, 2016 ve T.C. Gümrük ve Ticaret Bakanlığ, 2016.

\section{LITERATÜR TARAMASI}

İktisat literatüründe uluslararası turizm ile uluslararası ticaret ve dışa açıklık arasındaki neden-sonuç ilişkisini belirlemeye yönelik araştırmalar 1980'lerden sonra ampirik araştırmaların kapsamına girmiştir. Türkiye ile ilgili yapılan sınırlı sayıdaki dört çalışmada kullanılan ekonometrik yöntemler ve veri setlerindeki farklılıklar nedeniyle analiz sonuçları farklılıklar göstermektedir. Konuyla ilgili literatürde yer alan ulusal/uluslararası çalışmalardan bazılarını şu şekilde özetlemek mümkündür.

Kulendran ve Wilson (2000): Avusturalya, Japonya, Amerika, İngiltere ve Hollanda için 1982:q1-1997:q4 dönemi Granger nedensellik ve Engle-Granger eşbütünleşme yöntemleriyle üç farklı hipotezin (iş seyahatleri uluslararası 
Dokuz Eylül Üniversitesi İktisadi ve İdari Bilimler Fakültesi Dergisi

Cilt:32, Sayl:2, Yll:2017, ss. 79-107

ticareti etkiler; uluslararası ticaret uluslararası seyahatleri etkiler; iş seyahatleri haricinde diğer seyahatler uluslararası ticareti etkiler) geçerliliğini test etmişlerdir. Elde edilen bulgulara göre, uluslararası ticaret ve uluslararası seyahatler arasındaki nedensellik ilişkisi çift yönlüdür.

Wilson ve Shan (2001): Çin'de 1987:q1-1998:q1 dönemi uluslararası ticaret ve uluslararası turizm arasındaki ilişkiyi Toda-Yamamoto nedensellik analiziyle incelemiş ve değişkenler arasındaki nedensellik ilişkisinin çift yönlü olduğu sonucuna ulaşmışlardır.

Khan, vd. (2005): Singapur'da 1978:q1-2000:q3 dönemi ticaret (ihracat, ithalat ve toplam ticaret) ve seyahatler (iş, tatil ve toplam seyahatler) arasındaki ilişkiyi İngiltere, Japonya, Avusturalya ve ABD'yi dikkate alarak eşbütünleşme ve Granger nedensellik analizleriyle incelemişlerdir. Yapılan analizler sonucunda, kısa ve uzun dönemde Singapur ve diğer tüm ülkeler için iş seyahatleri ve ithalat arasında çift yönlü ilişki olduğu tespit edilmiştir.

Nowak, vd. (2007): İspanya'da 1960-2003 dönemi turizm, sermaye malları ihracatı ve büyüme arasındaki ilişkiyi Johansen eşbütünleşme ve Granger nedensellik analizleriyle incelemiş ve turizmden sermaye malları ihracatına, sermaye malları ihracatından büyümeye tek yönlü ilişki olduğunu bulmuşlardır.

Lana ve Fischer (2007): Almanya'da 1995:m1-2006:m7 dönemi uluslararas1 seyahat ve ticaret arasındaki ilişkiyi VAR, etki-tepki nedensellik analizleriyle incelemiş, nedenselliğin turist sayısından ihracata doğru tek yönlü olduğu sonucuna ulaşmışlardır.

Bahar ve Baldemir (2008): Türkiye'de 1980-2005 dönemi turizm ve ihracat arasındaki ilişkiyi regresyon ve Granger nedensellik analizleriyle incelemiş, turizmden ihracata pozitif, tek yönlü nedensellik ilişkisi olduğunu belirlemişlerdir.

Sun vd. (2008): Çin'de 1985-2005 dönemi 31 ilin dışa açıklık derecesi ile gelen turist sayısı arasındaki nedenselliğin pozitif olduğunu tahmin eden 


\section{H.TERZİ -A.TÜTÜNCÜ}

çalışmalarında, nedenselliğin dışa açıklıktan gelen turist sayısına doğru tek yönlü olduğu tespit edilmişlerdir.

Wong ve Tang (2008): Singapur'da 1986:q1-2008:q2 dönemi ülkeye gelen toplam turist sayısı ile mal ticaretinde dışa açıklık ilişkisini Toda-Yamamoto nedensellik yöntemiyle incelemiş, değişkenler arasındaki nedenselliğin çift yönlü olduğu sonucuna ulaşmışlardır.

Katırcıoğlu (2009): Yunanistan'da 1960-2005 dönemi turizm, ticaret, reel gelir ve büyüme arasında ilişkileri ARDL ve Granger nedensellik testleriyle incelemiş, uzun dönemde eşbütünleşme ilişkisinin olduğu, nedenselliğin kısa dönemde büyümeden turizme (ticarete), ticaretten turizme doğru tek yönlü olduğu sonucuna ulaşmıştır.

Sarmidi ve Salleh (2010): Malezya ve turizm ortaklarını (Singapur, Tayland, Endonezya ve Brunei Darussalam) dikkate alarak gelir, turizm ve ticaret (ihracat, ithalat ve toplam ticaret) arasındaki ilişkiyi 1997:q1-2007:q4 dönemi ARDL ve Granger nedensellik analizleri yardımıyla incelemişlerdir. Elde edilen bulgura göre, değişkenlerin uzun dönemde ilişkili ve kısa dönemde ise, Malezya ve Endonezya için, turizmden ihracata tek yönlü; Malezya ve Brunei Darussalam için turizm ile toplam ticaret ve ihracat arasında çift yönlü; turizmden ithalata tek yönlü ilişki olduğu belirlenmiştir.

Fry, vd. (2010): Güney Afrika'da 1992-2007 dönemi gelen turistler ve ticaret arasındaki ilişkiyi Pedroni eşbütünleşme ve Granger nedensellik analizleriyle incelemiş, değişkenler arasındaki nedenselliğin uzun dönemde çift yönlü olduğunu tespit etmişlerdir.

Polat, vd. (2010): Türkiye'de 1997:m1-2010:m1 dönemi turizm ve ticaret arasındaki ilişkiyi Granger nedensellik ve Johansen eşbütünleşme analizleriyle incelemişlerdir. Analizler sonucunda, değişkenler arasında eşbütünleşme ilişkisinin olmadığını ancak, nedenselliğin kısa dönemde gelen turist sayısından ithalata, turizm harcamalarından ihracata doğru tek yönlü; gelen turist sayısı 
(turizm harcamaları) ve ihracat (dış ticaret) arasında nedenselliğin kısa dönemde çift yönlü ilişki olduğunu tespit etmişlerdir.

Abbas ve İbrahim (2011): Mısır'da 1990-2008 dönemi uluslararası turizm ve dışa açıklık ilişkisini panel nedensellik-sabit etkiler yöntemiyle incelemiş, dışa açıklı̆̆ın turizm talebini 0,10 oranında pozitif yönde etkilediğini; nedenselliğin de dişa açiklıktan turizm talebine doğru tek yönlü olduğu sonucuna ulaşmışlardır.

Santana-Gallego, vd. (2011): OECD ülkelerinde 1980-2005 dönemi uluslararası turist sayısı ve ticaret arasındaki ilişkiyi panel eşbütünleşmeGranger nedensellik analizleriyle incelemiş, tamamlayıcılık ilişkisi nedeniyle uluslararası turizmin ekonomik büyümeyi de olumlu yönde etkileyeceğini ileri sürmüşlerdir. Elde edilen bulgulara göre, gelen turist sayısında \%1'lik artışın, dış ticareti \%0,76-1,73 oranında artıracağı; eşbütünleşmede tamamlayıcılık ilişkisine sahip değişkenler arasında kısa ve uzun dönemde nedenselliğin ihracattan turizme, gelen turist sayısından ithalata (dış ticarete) doğru tek yönlü olduğu sonucuna ulaşılmıştır.

Surugiu ve Surugiu (2011): Romanya'da 1990-2009 dönemi turizm ile dişa açıklık ilişkisini eşbütünleşme, vektör hata düzeltme ve Granger nedensellik analizleriyle incelemiş, eşbütünleşik değişkenler arasındaki nedenselliğin ticari dışa açıklıktan turizme doğru pozitif ve tek yönlü olduğunu tespit etmişlerdir.

Massidda ve Mattana (2012): İtalya'da 1987:q1-2009:q4 dönemi reel GSYIH, toplam ticaret ve turizm arasındaki ilişkileri Granger nedensellik ve eşbütünleşme analizleriyle araştırmış, toplam ticaretten turizme doğru tek yönlü ilişki olduğunu belirlemişlerdir.

Lee (2012): Singapur'da 1980-2007 dönemi ithalat-ihracat ve uluslararas1 turist sayısı arasındaki ilişkileri Sınır testi ve Granger nedensellik analizi ile incelemiş, turizme dayalı ithalatın ve ihracata dayalı turizm hipotezlerinin geçerli olduğunu ayrıca, nedenselliğin turizmden ithalata ve ihracattan turizme doğru tek yönlü olduğunu tahmin etmiştir. 


\section{H.TERZİ -A.TÜTÜNCÜ}

Vencovska (2014): Çek Cumhuriyeti ile 38 ülke arasında 2000-2012 dönemi uluslararası turist sayısı ile dışa açıklık ilişkisini dinamik panel-Arellano-Bond GMM tahmin yöntemleriyle incelemiş, iki değişken arasında istatistiksel olarak anlamlı bir ilişki olmadığını belirlemiştir.

Özcan ve Yorgancılar (2016): Türkiye'de 1963-2010 dönemi turist sayısı ile ithalat-ihracat-dış ticaret hacmi arasındaki ilişkileri VAR ve Toda-Yamamoto yaklaşımlarıyla incelemişlerdir. Elde edilen bulgulara göre, nedenselliğin VAR'da ihracat ile turist sayısı arasında çift yönlü, turist sayısından ithalata tek yönlü, dış ticaret ile turist sayısı arasında çift yönlü; Toda-Yamamoto yönteminde ise, turist sayısından ihracata ve ithalata tek yönlü ilişki olduğunu tespit etmişlerdir.

Tandoğan ve Genç (2016): Türkiye için 1980-2013 dönemi turizm geliriturist sayısı ile ticari açıklık ilişkisini Toda-Yamamoto yöntemiyle incelemiş, nedensellik ilişkisinin turizm gelirleri ile ticari açıklık arasında çift yönlü; ticari açıklıktan turist sayısına doğru tek yönlü olduğunu tahmin etmişlerdir.

Son yıllarda bu iki değişken arasındaki ilişkiyi inceleyen çalışmalar artmaktadır. Literatür, bu değişkenlerin ilişkili olduğunu göstermektedir. Genellikle uluslararası ticaretini arttıran ülkelerin daha dışa açık hale geldiği ve bunun sonucunda da uluslararası turizmini de arttırdığı gözlenmektedir. Uluslararası turizmini arttıran ülkelerin uluslararası ticaretini de arttırarak dışa açıklığını da arttırdığı görülmektedir (Santana-Gallego, Ledesma-Rodríguez ve Pérez-Rodríguez, 2011: 533-534). Böylelikle her ülke için bu iki değişkenin arasındaki ilişki önemli hale gelmektedir.

\section{EKONOMETRIKK YÖNTEMLER}

\subsection{Birim Kök Testleri}

Durağan olmayan serilerden oluşturulan sahte regresyon denkleminden elde edilen $\mathrm{t}$ ve $\mathrm{F}$ istatistiği değerlerine güvenilemez. $\mathrm{Bu}$ nedenle ekonometrik analizlerde kullanılan zaman serilerinin durağan oldukları seviyenin belirlenmesi sahte regresyonun oluşumunu önlemektedir. Bu çalışmada serilerin 
durağanlık seviyelerini belirlemek için Dickey ve Fuller (1981) tarafindan önerilen Geliştirilmiş Dickey Fuller (ADF) birim kök testine, Phillips ve Perron (1988) tarafından geliştirilen Phillips Perron (PP) birim kök testine başvurulmuştur. Dickey ve Fuller (1979) tarafindan geliştirilen Dickey-Fuller birim kök testi (DF) hata terimlerinde meydana gelen otokorelasyon sorununun düzeltilmesinde yetersiz kalmasını nedeniyle eleştirilmektedir. $\mathrm{Bu}$ nedenle Dickey ve Fuller (1981) çalışmasında ADF birim kök testini geliştirmiş̧ir. ADF birim kök testinde, DF birim kök testinden farklı olarak, denklemlere bağımlı değişkenin gecikmelerini eklenerek otokorelasyon sorunu giderilmeye çalışılmaktadır.

Phillips ve Perron (1988) çalışmasında ADF ve DF birim kök testlerinin serilerin durağanlık seviyelerini belirlerken yalnızca otoregresif süreçlere dikkat etmesini eleştirmektedirler; zaman serileri aynı zamanda hareketli ortalama sürecini de içerebilir. Böylelikle Phillips ve Perron (1988) zayıf bağımlı ve ADF birim kök testinin aksine hata terimlerinin heterojen dağılımına izin veren yeni bir yaklaşım önemektedir. Aynı zamanda PP birim kök testi ADF birim kök testine göre serilerde meydana gelebilecek yapısal kırılmaya daha duyarlıdır.

\subsection{Sims, Toda -Yamamoto ve Dolado-Lütkepohl VAR Analizi}

Sims (1980) tarafindan geliştirilen S-VAR (Sims' Standart Vektör Otoregresif) modelinde, bütün değişkenleri sistem içerisinde bir bütün olarak ele alınmaktadır. Böylece içsel ve dışsal değişken ayrımı yapılmamaktadır. $\mathrm{Bu}$ durumda, iktisadi olarak öne sürülmesi gereken herhangi bir teoriye ihtiyaç duymamaktadır. Ancak, sistemde yer alan her bir denklemdeki değişkenlerin gecikme uzunluğuna karar vermek önemlidir; gecikme uzunluğu uzun olduğunda gözlem kaybı yaşanırken, kısa olması durumunda model yanlış tahmin edilebilir. Bu durumda iki farklı görüş ileri sürülmüştür. Bunlardan biri, her bir denklem için gecikme uzunluğunun ayrı belirlenmesi, diğeri sistemde simetrinin sağlanması ve etkili EKK tahmincileri elde edilmesi için tüm denklemlerde aynı gecikme uzunluğunun kullanılmasıdır (Enders, 2015: 303). 


\section{H.TERZI -A.TÜTÜNCÜ}

Toda ve Yamamoto (1995) çalışmalarında, seriler durağan veya eşbütünleşik olmasalar dahi değişkenleri seviye değerleriyle kullanılabilen VAR modelinin nasıl tahmin edileceğini ve parametreler matrisindeki genel kısıtların nasıl test edileceğini göstermektedirler. $\mathrm{Bu}$ yöntemde serilerin durağanlık seviyeleri önemli değildir. Fakat modeli doğru oluşturabilmek için serilerin maksimum durağanlık seviyeleri tespit edilmelidir. Ayrıca bu yöntemin uygulanabilmesi için ele alınan değişkenlerin $\mathrm{I}(0), \mathrm{I}(1)$ veya $\mathrm{I}(2)$ seviyesinde durağan olması gerekmektedir; çünkü Toda ve Yamamoto $(1995 ; 233)$ zaman serilerinin uygulamada en çok I(2) düzeyinde durağanlıklarının gerçekleşeceğini ifade etmektedir. $\mathrm{Bu}$ nedenden dolayı $\left(\mathrm{d}_{\max }\right)$ değerinin maksimum 2 olacağını varsaymaktadırlar. Buna ek olarak, değişkenlerin hepsinin I(0) olduğu durumda $\mathrm{d}_{\max }=0$ olacağından S-VAR modeli kullanılmalıdır.

Zaman serileri entegre veya eşbütünleşik olduğunda Granger nedensellik analizini test etmek için kullanılan geleneksel $\mathrm{F}$ istatistiği standart bir dağılıma sahip olmayabilir (Wolde-Rufael, 2005: 895). Bu durumda Toda ve Yamamoto (1995), değişkenler arasında eşbütünleşme ilişkisi olmadığı durumda da kullanılabilen ve WALD istatistiğinin asimtotik dağılımını garantileyen geliştirilmiş VAR tahmincilerini oluşturmuşlardır (Zapata ve Rambaldi, 1997: 285). Bu durumda modelin öncelikle gecikme uzunluğu değeri olan $\mathrm{k}$ belirlenir. Daha sonra modeldeki değişkenlere ait en yüksek durağanlık seviyesi $\left(\mathrm{d}_{\max }\right)$ tespit edilir. $\left(\mathrm{d}_{\max }\right)$ derecesi $\mathrm{k}$ gecikmeli VAR modeline dişsal değişken olarak eklenerek geliştirilmiş VAR modeli çözülür. Modelde $\mathrm{d}_{\max }$ gecikmeli vektörlerin katsayılar matrisi dikkate alınmaz ve standart asimtotik teoride kullanılan $\mathrm{k}$ gecikmeli katsayılar matrisi için doğrusal ve doğrusal olmayan kısıtlar test edilir (Toda ve Yamamoto, 1995: 245). Geliştirilmiş $\operatorname{VAR}\left(\mathrm{k}+\mathrm{d}_{\max }\right)$ modelinde Toda ve Yamamoto (1995)'nun önerdiği $\chi^{2}$ dağılımına sahip modifiye edilmiş Wald testi (MWALD) kullanılır. Böylece bu yöntem, serilerin durağanlık ve eşbütünleşme derecelerinin belirlenmesinde oluşabilecek riskleri minimize eder (Lee, 2006: 1088).Granger nedensellik testinde seriler farkı alınıp kullanıldığında, seriler hakkında bilgi kaybı meydana gelmektedir. Ayrıca bu 
testin kullanımında eşbütünleşme gibi ön testlerin yapılması gerekmektedir. Toda ve Yamamoto (1995) bu problemin üstesinden gelebilmek için VAR modeline, serilerin maksimum durağanlık derecesi kadar gecikme uzunluğu eklemektedir. Bu problemin üstesinden gelen bir diğer yöntem ise, Dolado ve Lütkepohl (1996) tarafindan geliştirilmiştir. Dolado ve Lütkepohl (1996) çalışmalarında, Toda-Yamamoto (TY-VAR) yöntemi gibi geliştirilmiş VAR modelinde kullanılan yeni bir Granger nedensellik testi önermektedir(Yılanc1 ve Bozoklu, 2014: 213). S-VAR sürecinde katsayıların kısıtlamalarında kullanılan Wald testi, değişkenler I(1) ve eşbütünleşik olduğunda standart olmayan asimtotik özelliklere sahip olmaktadır. $\mathrm{Bu}$ nedenle genel şartlar altında asimtotik $\chi^{2}$ dağılımına sahip Wald testinin kullanılması için Dolado-Lütkepohl (DL-VAR) yöntemi, basit bir yöntem kullanılarak uygulanmaktadır. Bu amaçla, $\operatorname{VAR}(k)$ sürecini oluşturmak için $\operatorname{VAR}(k+1)$ süreci önerilmektedir. Wald testi ise yalnızca VAR(k) süreci kullanılarak uygulanmalıdır (Dolado ve Lütkepohl, 1996: 1).

TY-VAR yöntemine göre, ekonomik seriler en fazla I(2) de durağan olduğu için $d_{\max }$ derecesi en fazla iki olarak alınmaktadır. Ancak, DL-VAR yönteminde nedensellik, testinin gücü $\mathrm{d}_{\max }=1$ olduğunda daha yüksek olacağ 1 için geliştirilmiş VAR modelinde optimal gecikme uzunluğuna bir gecikme ilave edilmektedir (Apergis ve Tang, 2013: 27).TY-VAR ve DL-VAR yöntemleri arasındaki bir diğer fark ise, TY-VAR yönteminde ilave gecikme uzunluğu modele dişsal değişken olarak eklenirken DL-VAR yönteminde içsel değişken olarak eklenmektedir. Ayrıca Dolado ve Lütkepohl (1996: 6-16) çalışmalarında, eğer değişkenlerin durağanlık seviyesi $\mathrm{I}(1)$ veya $\mathrm{I}(0)$ olduğu hakkında kesin bilgi elde edilemiyorsa, S-VAR modeline ilave bir gecikme uzunluğu ilave edilebileceğini ifade etmektedir. Buna ek olarak, değişkenlerin durağanlık seviyesi $I(d), d>1$ olduğunda ise, geliştirilmiş VAR modelinde $d$ değeri kadar ilave değişken eklenebileceğini belirtmektedir. 


\section{VERİ SETİ}

\section{H.TERZİ -A.TÜTÜNCÜ}

Türkiye'nin turizm gelirleri (TG) ve ticari dışa açıklık (TA) arasındaki ilişkiyi inceleyen bu çalışmada, 1985-2014 dönemi analiz edilmiştir.

Tablo 2. Veri Seti

\begin{tabular}{|c|l|c|}
\hline Değişken & \multicolumn{1}{|c|}{ Açıklaması } & Kaynak \\
\hline Dışa açıklık & $\begin{array}{l}\text { Toplam dış ticaretin (ihracat+ithalat) } \\
\text { GSYİH içerisindeki payı. }\end{array}$ & Dünya Bankası \\
\hline Turizm gelirleri & $\begin{array}{l}2005 \text { dolar bazlı GSYİH deflatörü ile } \\
\text { reel hale getirilmiştir. }\end{array}$ & $\begin{array}{c}\text { Türkiye İstatistik } \\
\text { Kurumu }\end{array}$ \\
\hline
\end{tabular}

Serilere ait gözlem değerlerinin logaritması alındıktan sonra ekonometrik modeller uygulanmıştır. Şekil 4'de sol eksen dışa açıklık, sağ eksen turizm gelirlerine ait değerleri ifade etmektedir. Şekil 4'e göre, dışa açıklıkta yıllar itibariyle artan bir trend olsa da büyük değişiklikler olmamıştır. Turizm gelirleri ise, her ne kadar 1999 yılında büyük bir azalış yaşasa da dışa açıklığa göre daha hızlı bir şekilde artmaktadır.

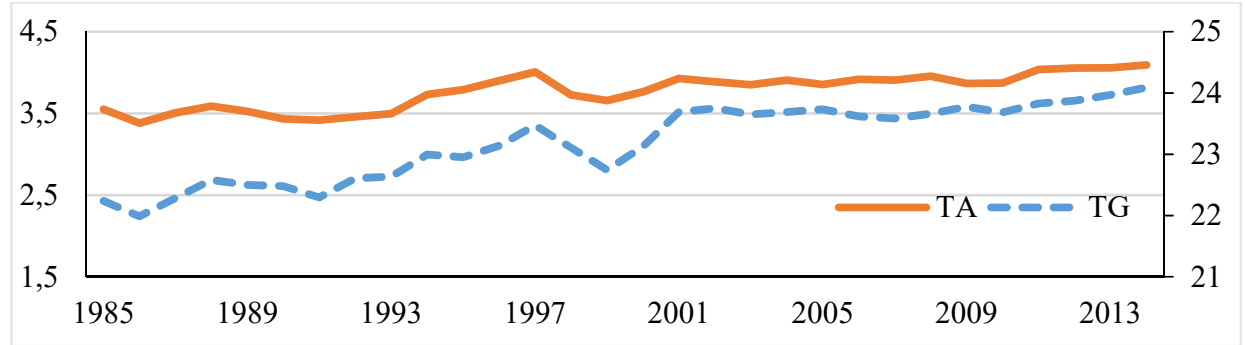

Şekil 4. Dışa Açıklık ve Turizm Gelirleri

Turizm gelirleri ve dışa açıklık değişkenlerine ait tanımlayıcı istatistiklere Tablo 3'de yer verilmiştir. Tablo 3'de değişkenlere ait ortanca (M) ve ortalama $(\overline{\mathrm{X}})$ değerler birbirlerine yakındır, aynı zamanda eğiklik ve basıklık değerleri her iki değişkenin normal dağıldığını işaret etmektedir. Standart sapma (SS) değerinin sıfıra yakın olması beklenmektedir. Çarpılık (S) ve basıklık (K) istatistikleri de beklentiye uygundur. Jarque-Bera (JB) testinin p-değeri her iki değişkenin normal dağılıma sahip olduğunu göstermektedir. 
Tablo 3. Değişkenlere Ait Tanımlayıcı İstatistikler

\begin{tabular}{|c|c|c|c|c|c|c|c|c|}
\hline & $\overline{\mathrm{X}}$ & $\mathrm{M}$ & Maks. & Min. & SS & S & K & JB-(p) \\
\hline TG & 23,19 & 23,30 & 24,08 & 21,98 & 0,61 & $-0,36$ & 1,74 & 0,64 \\
\hline TA & 3,77 & 3,85 & 4,09 & 3,38 & 0,21 & $-0,36$ & 1,84 & 0,31 \\
\hline
\end{tabular}

\section{BULGULAR VE DEĞERLENDİRMELER}

Çalışmada, Sims (1980), Toda-Yamamoto (1995) ve Dolado-Lütkepohl (1996) tarafından önerilen VAR nedensellik yöntemleri kullanılmıştır.

Nedensellik analizlerinde önce değişkenler arasında yapılan korelasyon analizinin sonuçları Tablo 4'de gösterilmiştir. Yapılan çift yönlü korelasyon analizine göre, değișkenler arasında pozitif ve anlamlı bir ilișki vardır. Bu durum değişkenler arasında bir ilişki olabileceğini işaret etmektedir.

Tablo 4. Korelasyon Matrisi

\begin{tabular}{|c|c|c|}
\hline Değişkenler & TG & TA \\
\hline TG & 1 & $0,946^{*}$ \\
\hline TA & $0,946^{*}$ & 1 \\
\hline
\end{tabular}

${ }^{*}$ Çift yönlü t testine göre 0,01 'de anlamlı

Çalışmada kullanılan değişkenlerin $d_{\max }$ derecelerinin belirlenebilmesi amacıyla, değişkenler durağanlık testine tabi tutulmuşlardır. Bu amaçla ADF ve PP birim kök testlerinden yararlanılmıştır. ADF birim kök testine göre, TG değişkeni sabitli ve trendli modelde $\mathrm{I}(0)$ seviyesinde 0,10 anlamlılık düzeyinde istatiksel olarak anlamlı olmasına rağmen, PP birim kök testine göre her iki modelde de I(1) seviyesinde anlamlıdır. Bu durumda TY-VAR yöntemine göre, uygulanacak olan geliştirilmiş VAR modelinde $d_{\max }=1$ olarak analize dahil edilmiştir.

Tablo 5. ADF Birim Kök Testi

\begin{tabular}{|l|c|c|c|c|}
\hline \multirow{2}{*}{ Değişkenler } & \multicolumn{2}{|c|}{ Sabitli Model } & \multicolumn{2}{c|}{ Sabitli ve Trendli Model } \\
\cline { 2 - 5 } & $\mathrm{I}(0)$ & $\mathrm{I}(1)$ & $\mathrm{I}(0)$ & $\mathrm{I}(1)$ \\
\hline TG & $-1,04$ & $-5,74^{*}$ & $-3,92^{* * *}$ & $-5,64^{*}$ \\
\hline TA & $-1,08$ & $-5,33^{*}$ & $-3,02$ & $-5,21^{*}$ \\
\hline
\end{tabular}

Not: Optimal gecikme uzunluğu Schwarz Bilgi Kriteri kullanılarak elde edilmiştir. ${ }^{*}$ ve ${ }^{* * *}$ sirasiyla 0,01 ve 0,10 'da anlamlı. 


\section{H.TERZİ -A.TÜTÜNCÜ}

Tablo 6. PP Birim Kök Testi

\begin{tabular}{|c|c|c|c|c|}
\hline \multirow{2}{*}{ Değişkenler } & \multicolumn{2}{|c|}{ Sabitli Model } & \multicolumn{2}{c|}{ Sabitli ve Trendli Model } \\
\cline { 2 - 5 } & $\mathrm{I}(0)$ & $\mathrm{I}(1)$ & $\mathrm{I}(0)$ & $\mathrm{I}(1)$ \\
\hline TG & $-0,63$ & $-7,52^{*}$ & $-2,90$ & $-9,32^{*}$ \\
\hline TA & $-0,66$ & $-8,60^{*}$ & $-2,86$ & $-9,10^{*}$ \\
\hline
\end{tabular}

Not: Band genişliği BartelttKernel yöntemine göre belirlenmiştir. * 0,01'de anlamlı.

DL-VAR yönteminde ise, $\mathrm{d}_{\max }=1$ olarak alınmasının önerilmesinin yanı sıra, maksimum durağanlık seviyesinin de I(1) olarak belirlenmesinden dolayı bu test için kullanılacak maksimum durağanlık seviyesi de 1 olarak dikkate alınmıştır.

Çalışmada kullanılan nedensellik analizlerin biri, S-VAR modeli kullanılarak hesaplanan Granger nedensellik testidir. Bu test için (1) ve (2) numaralı denklemler kullanılmıştır. Aşağıdaki denklemlerde yer alan TG, turizm gelirlerini; TA, dışa açıklığ $1 ; e_{t}$ ve $v_{t}$ hata terimlerini ifade etmektedir.

$$
\begin{aligned}
& \Delta \mathrm{TG}_{\mathrm{t}}=\varphi_{0}+\sum_{\mathrm{i}=1}^{\mathrm{k}} \varphi_{1 \mathrm{i}} \Delta \mathrm{TG}_{\mathrm{t}-\mathrm{i}}+\sum_{\mathrm{i}=1}^{\mathrm{k}} \varphi_{2 \mathrm{i}} \Delta \mathrm{TA}_{\mathrm{t}-1}+\mathrm{e}_{\mathrm{t}} \\
& \Delta \mathrm{TA}_{\mathrm{t}}=\vartheta_{0}+\sum_{\mathrm{i}=1}^{\mathrm{k}} \vartheta_{1 \mathrm{i}} \Delta \mathrm{TA}_{\mathrm{t}-\mathrm{i}}+\sum_{\mathrm{i}=1}^{\mathrm{k}} \vartheta_{2 \mathrm{i}} \Delta \mathrm{TG}_{\mathrm{t}-1}+\mathrm{v}_{\mathrm{t}}
\end{aligned}
$$

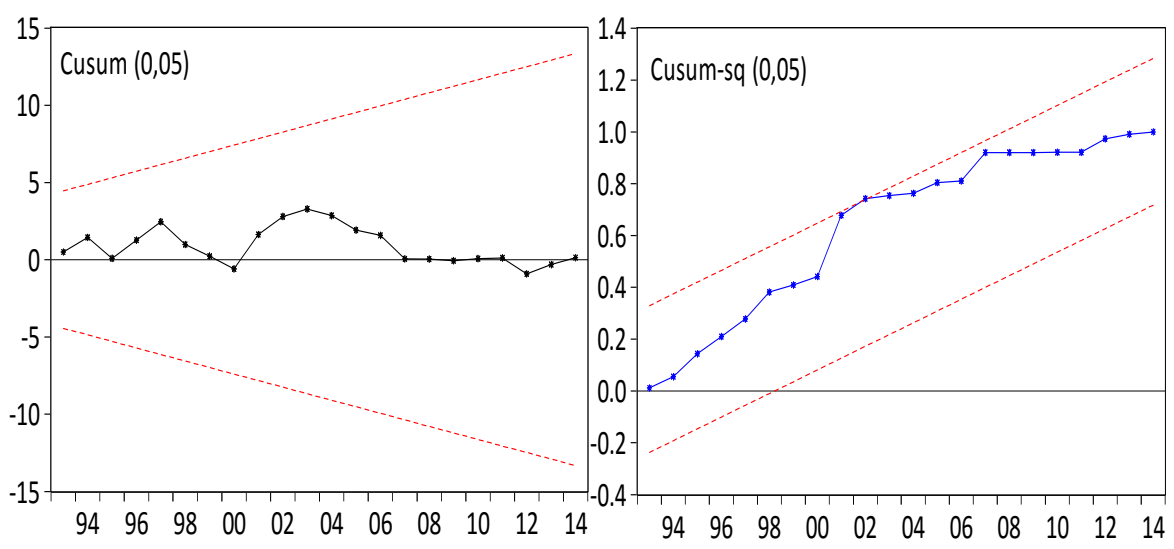

Şekil 5. (1) Numaralı Denkleme Ait Cusum ve Cusum-sqDeğerleri 


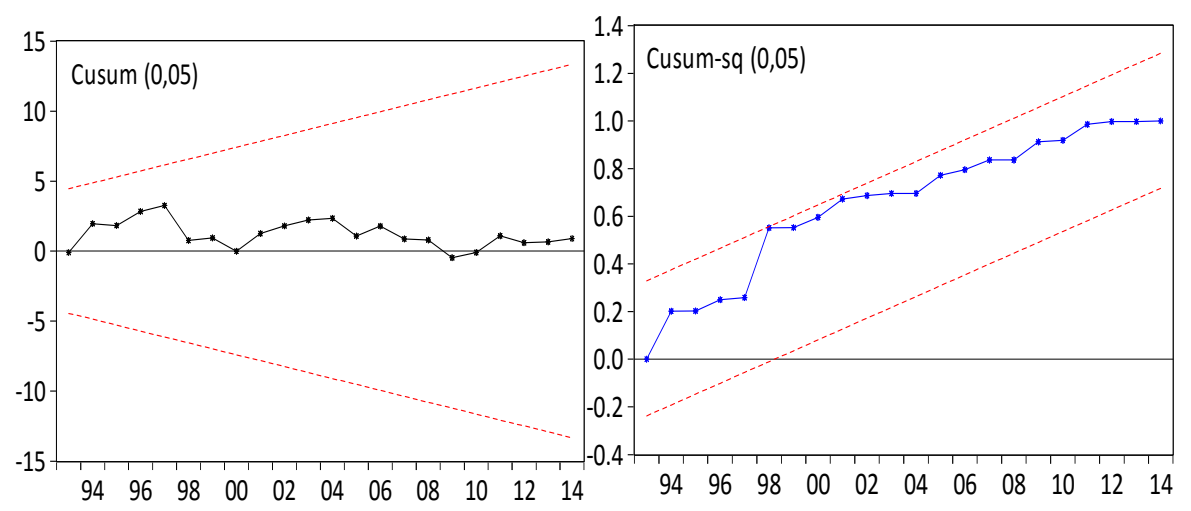

Şekil 6. (2) Numaralı Denkleme Ait Cusum ve Cusum-sqDeğerleri

Diagnostik testler dikkate alındığında optimal gecikme uzunluğu 2 olarak belirlenmiştir. $\mathrm{Bu}$ gecikme uzunluğunda diagnostik problemlerle karşılaşılmamıştır. Aynı zamanda Şekil 5 ve Şekil 6'da görüldüğü gibi, Cusum ve Cusum-sq değerleri de bandın içerisinde devam ettiğinden modeller istikrarlıdır. Elde edilen sonuçlara göre, dışa açıklıktan turizm gelirlerine doğru pozitif ve istatistiksel olarak anlamlı ilişki mevcutken, turizm gelirden dişa açıklığa doğru istatistiksel olarak anlamlı bir ilişki bulunamamıştır. Sonuçlar Tablo 7'de özetlenmiştir.

Tablo 7. S-VAR Analizi Sonuçları

\begin{tabular}{|c|l|l|}
\hline $\mathrm{H}_{0}$ Hipotezi & $\chi^{2}$ İstatistiği & Diagnostik Testler \\
\hline $\mathrm{TA} \nRightarrow \mathrm{TG}$ & $4,63(0,09)$ & $\mathrm{F}_{\mathrm{LM}}=1,11(0,34) ; \mathrm{R}^{2}=0,36$ \\
& & $\mathrm{~F}_{\mathrm{Glejser}}=0,88(0,52) ; \mathrm{JB}=0,01(0,99)$ \\
\hline $\mathrm{TG} \nRightarrow \mathrm{TA}$ & $1,12(0,57)$ & $\mathrm{F}_{\mathrm{LM}}=0,32(0,72) ; \mathrm{R}^{2}=0,16$ \\
& & $\mathrm{~F}_{\mathrm{Glejser}}=0,33(0,91) ; \mathrm{JB}=3,85(0,14)$ \\
\hline
\end{tabular}

Not: Parantez içerisindeki ifadeler olasıllk değerleridir.

TY-VAR yöntemine göre kullanılacak denklemler aşağıda ifade edilmiştir. (3) numaralı denklem dışa açıklıktan turizm gelirlerine doğru nedenselliğin varlığını test etmektedir. Bunun yanı sıra (4) numaralı denklem ise, turizm gelirlerinden dışa açıklığa doğru bir nedensellik ilişkisinin olup olmadığını test etmektedir. 


$$
\begin{gathered}
\text { H.TERZİ -A.TÜTÜNCÜ } \\
\mathrm{TG}_{\mathrm{t}}=\lambda_{0}+\lambda_{1} \mathrm{t}+\sum_{\mathrm{i}=1}^{\mathrm{k}} \gamma_{1 \mathrm{i}} \mathrm{TG}_{\mathrm{t}-\mathrm{i}}+\sum_{\mathrm{j}=\mathrm{k}+1}^{\mathrm{k}+\mathrm{d}_{\max }} \gamma_{2 \mathrm{j}} \mathrm{TG}_{\mathrm{t}-\mathrm{j}}+ \\
\sum_{\mathrm{i}=1}^{\mathrm{k}} \pi_{1 \mathrm{i}} \mathrm{TA}_{\mathrm{t}-\mathrm{i}}+\sum_{\mathrm{j}=\mathrm{k}+1}^{\mathrm{k}+\mathrm{d}_{\max }} \pi_{2 \mathrm{j}} \mathrm{TA}_{\mathrm{t}-\mathrm{j}}+\mathrm{z}_{\mathrm{t}} \\
\mathrm{TA}_{\mathrm{t}}=\pi_{0}+\pi_{1} \mathrm{t}+\sum_{\mathrm{i}=1}^{\mathrm{k}} \theta_{1 \mathrm{i}} \mathrm{TA}_{\mathrm{t}-\mathrm{i}}+\sum_{\mathrm{j}=\mathrm{k}+1}^{\mathrm{k}+\mathrm{d}_{\max }} \theta_{2 \mathrm{j}} \mathrm{TA}_{\mathrm{t}-\mathrm{j}}+ \\
\sum_{\mathrm{i}=1}^{\mathrm{k}} \beta_{1 \mathrm{i}} \mathrm{TG}_{\mathrm{t}-\mathrm{i}}+\sum_{\mathrm{j}=\mathrm{k}+1}^{\mathrm{k}+\mathrm{d}_{\max }} \beta_{2 \mathrm{j}} \mathrm{TG}_{\mathrm{t}-\mathrm{j}}+\mathrm{v}_{\mathrm{t}}
\end{gathered}
$$

$\mathrm{z}_{\mathrm{t}} \mathrm{vev}_{\mathrm{t}}$ ise,hata terimlerini ifade etmektedir. Ayrica denklemlerde t olarak yer verilen trend terimi anlamlı bir değişken olduğu için denklemlere dahil edilmiştir. TY-VAR $\left(k+d_{\max }\right)$ analizinde optimal gecikme uzunluğu $(\mathrm{k})$ ve maksimum durağanlık derecesi $\left(\mathrm{d}_{\max }\right), 1$ olarak belirlenmiştir. Böylelikle hesaplanan TY-VAR(2) analiz sonuçları ve diagnostik testleri Tablo 8'de gösterilmiştir.

Tablo 8. TY-VAR(2) Analiz Sonuçları

\begin{tabular}{|l|c|l|l|}
\hline $\begin{array}{l}\mathrm{H}_{0} \\
\text { Hipotezi }\end{array}$ & Katsayı1S1 & $\chi^{2}$ İstatistiği & Diagnostik Testler \\
\hline $\begin{array}{l}\mathrm{TA} \Rightarrow \mathrm{TG} \\
\left(\pi_{11}=0\right)\end{array}$ & 1,07 & $3,54(0,05)$ & $\begin{array}{l}\mathrm{F}_{\mathrm{LM}}=0,61 \quad(0,55) ; \quad \mathrm{F}_{\mathrm{Glejser}}=1,19 \\
(0,34) ; \mathrm{JB}=0,61(0,73) ; \mathrm{R}^{2}=0,92\end{array}$ \\
\hline $\begin{array}{l}\mathrm{TG} \neq \mathrm{TA} \\
\left(\beta_{11}=0\right)\end{array}$ & $-0,19$ & $2,02(0,15)$ & $\begin{array}{l}\mathrm{F}_{\mathrm{LM}}=0,19 \quad(0,82) ; \quad \mathrm{F}_{\mathrm{Glejser}}=0,90 \\
(0,47) ; \mathrm{JB}=0,60(0,73) ; \mathrm{R}^{2}=0,85\end{array}$ \\
\hline
\end{tabular}

Not: Parantez içerisindeki ifadeler olasılık değerlerini ifade etmektedir.

TY-VAR(2) modeline göre hesaplanan Granger nedensellik testi S-VAR modeline göre hesaplanan modelle aynı sonucu vermektedir. Nedensellik istatistiksel olarak anlamlı ve tek yönlü olup dışa açıklıktan turizm gelirlerine doğrudur. Her iki denkleme ait diagnostik test sonuçları ve Şekil7 ve Şekil8'de ifade edilen Cusum değerleri de denklemlerde sorun olmadığını göstermektedir.

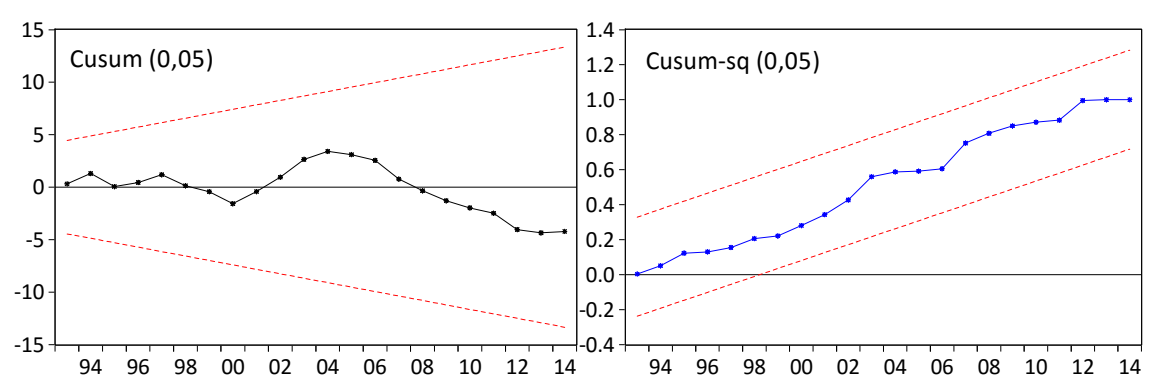

Şekil 7. (3) Numaralı Denkleme Ait Cusum ve Cusum-sq Değerleri 

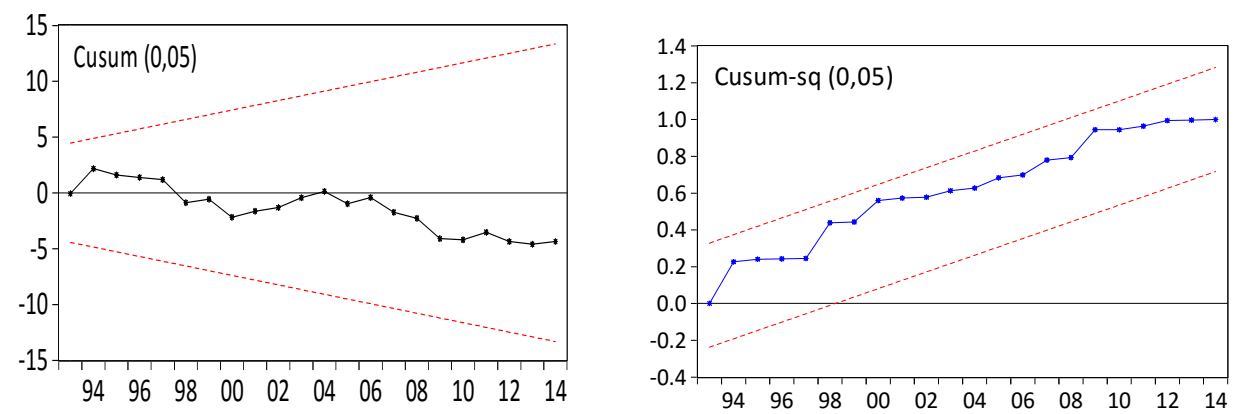

Şekil 8. (4) Numaralı Denkleme Ait Cusum ve Cusum-sq Değerleri

TY-VAR(2) modeli dikkate alınarak hesaplanan korelasyon matrisinin değeri $(0,77)$ 0,25'den büyük olduğu için varyans ayrıştırma ve etki-tepki fonksiyonlarının hesaplanmasında genelleştirilmiş varyans ayrıştırma (GVA) ve genelleştirilmiş etki-tepki (GET) fonksiyonları kullanılmıştır. ET analizi, VAR'daki bir değişkende meydana gelen şokun diğer değişkenler üzerindeki etkisini, VA analizi ise, VAR'daki bir değişkendeki yüzde değişmenin ne kadarının kendisinden ve diğer değişkenlerden meydana geldiğini gösterdiğinden ET ve VA nedenselliğin yönü hakkında fikir vermektedir. Bu çalışmada VAR analizinde modelde değişkenlerin içsel-dışsal sıralamasına duyarlı Cholesky’nin ayrıştırma yöntemi yerine sıralamaya duyarsız olan ancak yüzde değişmede toplam \%100 limitini aşan Genelleştirilmiş ET ve VA yöntemleri kullanılmıştır.

Şekil 9'da GVA analizinde dışa açıklıkta meydana gelen şoklar genellikle kendisi tarafından açıklanmakta ve yıllar itibariyle bu durumda önemli bir değişme meydana gelmemektedir. Şekil 10’da da, turizm gelirlerde meydana gelen değişmede kendisinin ve dışa açıklığın payının benzer olduğunu, dışa açıklığın turizm gelirlerinde meydana gelen değişmeyi etkilediği görülmektedir. 
H.TERZİ -A.TÜTÜNCÜ

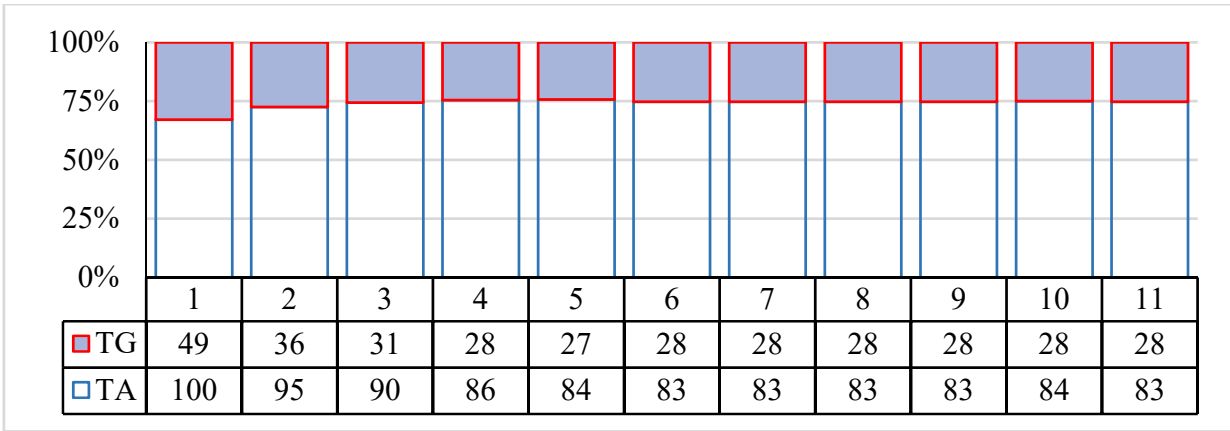

Şekil 9. Dışa Açıklığın Genelleştirilmiş Varyans Ayrıştırması

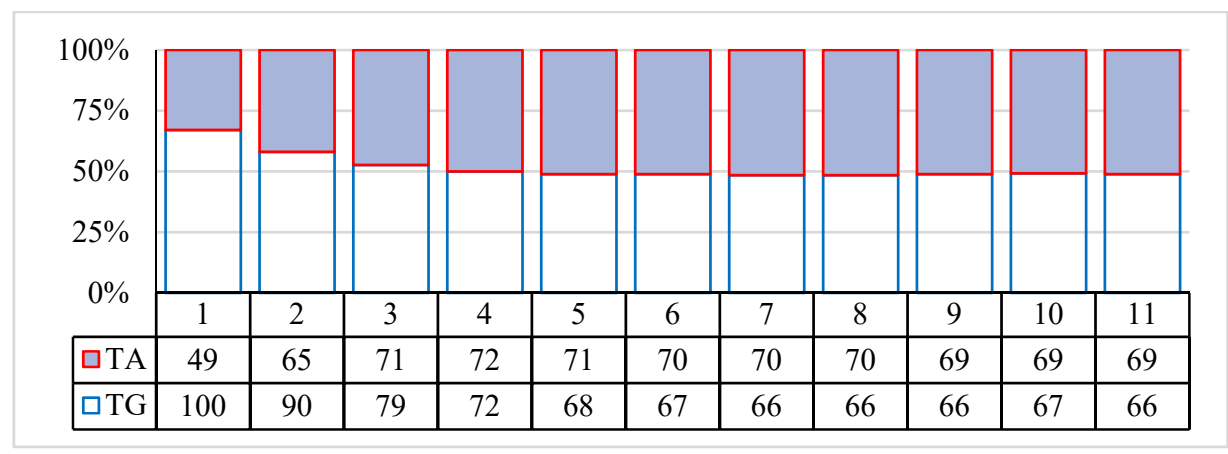

Şekil 10. Turizm Gelirlerinin Genelleştirilmiş Varyans Ayrıştırması

Dışa açıklığın turizm gelirlerine tepkisi dikkate alındığında, turizm gelirlerinde meydana gelen bir birimlik şoka dışa açıklık ilk dönem en yüksek tepkiyi vermiştir. İkinci yılın sonuna kadar dışa açıklığın pozitif olarak seyrederken, üçüncü yılda negatif tepki oluşmaya başlamıştır. Negatif tepkinin en yüksek olduğu dönem beşinci yıldır, daha sonra negatif tepki giderek azalmaktadır.

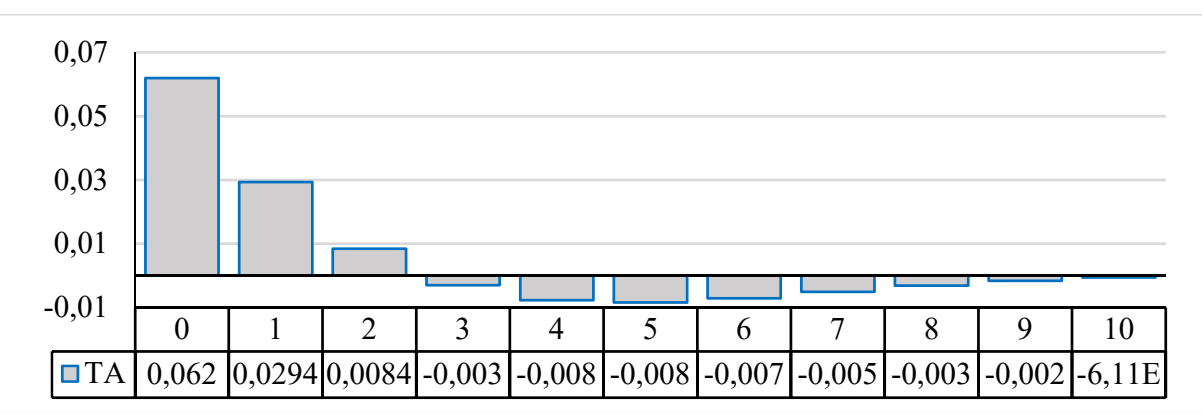

Şekil 11. Dışa Açıklığın Turizm Gelirlerine Tepkisi 
Turizm gelirlerinin dışa açıklığa verdiği tepkiyi gösteren Şekil 12 incelendiğinde, dışa açıklıkta meydana gelen bir birimlik şoka turizm gelirleri ilk altı dönem pozitif tepki vermiştir. İlerleyen dönemde ise, bu tepki negatif olarak devam etmiştir, ancak negatif tepki -0,01'i geçmemiştir.

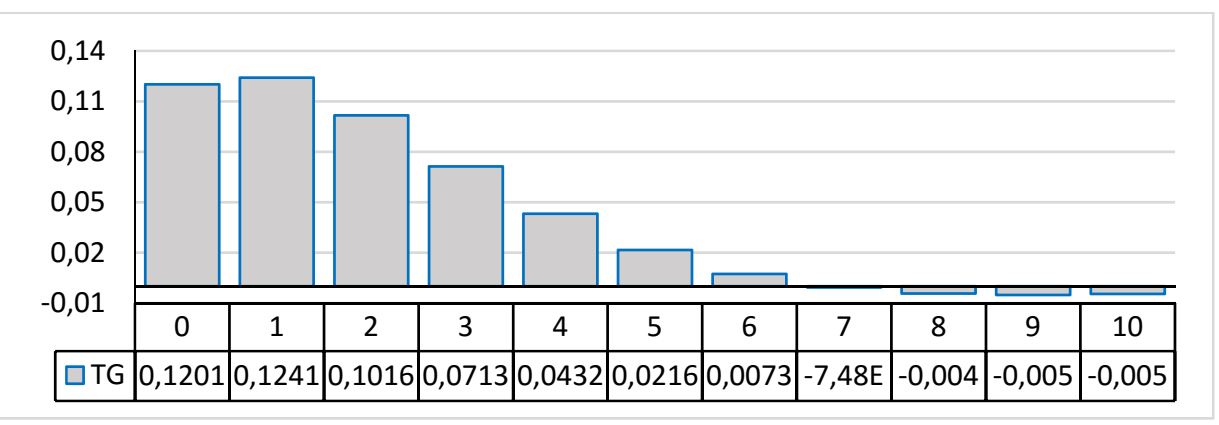

Şekil 12. Turizm Gelirlerinin Dışa Açıklığa Tepkisi

GET fonksiyonlarına göre ise, her iki değişkene de verilen bir birimlik şoka ilk olarak pozitif tepki verdikleri, fakat daha sonra bu tepkinin negatif olduğu görülmektedir. Toplam tepkiler dikkate alındığında, turizm gelirlerinde meydana gelen bir birimlik şoka dışa açıklığın tepkisi, dışa açıklıkta meydana gelen bir birimlik şoka turizm gelirlerinin verdiği tepkiden daha küçüktür. $\mathrm{Bu}$ durumda GET fonksiyonlarının ve GVA analizinin TY-VAR(2) modelinden elde edilen sonuçları desteklediği görülmektedir.

Çalışmada kullanılan DL-VAR nedensellik analizi, (5) ve (6) numaralı denklemler yardımıyla gösterilmiştir. (5) numaralı denklem dışa açıklıktan turizm gelirlerine doğru nedenselliğin varlığını test ederken, (6) numaralı denklem ise, turizm gelirlerinden dışa açıklığa doğru nedenselliğin varlığını test etmektedir. TY-VAR testinde olduğu gibi bu testte de trend anlamlı bir değişkendir ve bu nedenle denklemlerde trende yer verilmiştir. $\varepsilon_{\mathrm{t}}$ ve $\epsilon_{\mathrm{t}}$ ise hata terimlerini ifade etmektedir.

$$
\begin{aligned}
& \mathrm{TG}_{\mathrm{t}}=\phi_{0}+\phi_{1} \mathrm{t}+\sum_{\mathrm{j}=1}^{\mathrm{k}+\mathrm{d}_{\max }} \Omega_{1 \mathrm{j}} \mathrm{TG}_{\mathrm{t}-\mathrm{j}} \sum_{\mathrm{j}=1}^{\mathrm{k}+\mathrm{d}_{\max }} \Omega_{2 \mathrm{j}} \mathrm{TA}_{\mathrm{t}-\mathrm{j}}+\varepsilon_{\mathrm{t}} \\
& \mathrm{TA}_{\mathrm{t}}=\alpha_{0}+\alpha_{1} \mathrm{t}+\sum_{\mathrm{j}=1}^{\mathrm{k}+\mathrm{d}_{\max }} \omega_{1 \mathrm{j}} \mathrm{TG}_{\mathrm{t}-\mathrm{j}} \sum_{\mathrm{j}=1}^{\mathrm{k}+\mathrm{d}_{\max }} \omega_{2 \mathrm{j}} \mathrm{TA}_{\mathrm{t}-\mathrm{j}}+\epsilon_{\mathrm{t}}
\end{aligned}
$$




\section{H.TERZİ -A.TÜTÜNCÜ}

DL-VAR analizi için uygulanacak olan geliştirilmiş $\operatorname{VAR}\left(\mathrm{k}+\mathrm{d}_{\max }\right)$ modelinde de TY-VAR testinde olduğu gibi gecikme uzunluğu $\mathrm{k}+\mathrm{d}_{\max }=2$ olarak analize dahil edilmiştir. Böylelikle değişkenler arasındaki ilişki DL-VAR(2) modeli yardımıyla ele alınmıştır. Daha öncede değinildiği gibi, TY-VAR analizinde $\mathrm{d}_{\max }$ gecikme uzunluğu modele dişsal değişken olarak ilave edilirken DL-VAR analizinde içsel değişken olarak ilave edilmektedir.

Tablo 9. DL-VAR(2) Analiz Sonuçları

\begin{tabular}{|c|c|c|c|}
\hline $\mathrm{H}_{\mathrm{o}}$ Hipotezi & Katsayı1 1 & $\chi^{2}$ İstatistiği & Diagnostik Testler \\
\hline $\mathrm{TA} \nRightarrow \mathrm{TG}$ & 1,07 & $3,54(0,05)$ & $\mathrm{F}_{\mathrm{LM}}=0,61(0,55) ; \mathrm{F}_{\mathrm{Glejer}}=1,19$ \\
$\left(\Omega_{21}=0\right)$ & & & $(0,34) \mathrm{R}^{2}=0,82 ; \mathrm{JB}=0,61(0,73)$ \\
\hline $\mathrm{TG} \Rightarrow \mathrm{TA}$ & $-0,19$ & $2,02(0,15)$ & $\mathrm{F}_{\mathrm{LM}}=0,19 ;(0,82) ; \mathrm{F}_{\mathrm{Glejser}}=0,90(0,47)$ \\
$\left(\omega_{11}=0\right)$ & & & $\mathrm{R}^{2}=0,85 ; \mathrm{JB}=0,60(0,73)$ \\
\hline
\end{tabular}

Not:Parantez içerisindeki rakamlar olasılık değerleridir.

DL-VAR(2) modeli dikkate alınarak EKK yöntemi ile çözülen denklemlerden elde edilen sonuçlar ise, Tablo 9'da belirtilmiştir. Her iki modelde de geliştirilmiş VAR modelinin derecesi aynı olduğu için DLVAR(2)'den elde edilen sonuçlar TY-VAR(2) modelinden elde edilen sonuçlarla aynıdır. Böylelikle dışa açıklıktan turizm gelirlerine doğru bir nedenselliğin olduğu söylenebilir. Bu nedensellik tek yönlü, pozitif ve 0,05 seviyesinde istatistiksel olarak anlamlıdır. Cusum ve Cusum-sq değerleri TYVAR(2) analizinden elde edilen Şekil 7 ve Şekil 8 ile aynı değerlere sahiptir.

Çalışmada yer kaplamaması açısından S-VAR(2), TY-VAR(2) ve DLVAR(2) analiz sonuçlarına ait diagnostik testler tek bir tablo halinde Tablo 10 'da ifade edilmiştir. Tablodan da görüldüğü üzere, her model diagnostik açıdan uygundur; otokorelasyon ve değişen varyans problemi yoktur ve modeller normal dağılıma uygundur. Aynı zamanda AR köklerinin değerleri birden küçük olduğu için modeller istikrarlıdır. S-VAR(2), TY-VAR(2) ve DLVAR(2) analizlerine ait diagnostik testler modellerin ekonometrik açıdan kabul edilebilir olduğunu, Cusum ve Cusum-sq değerleri de incelenen dönemin istikrarlı olduğunu göstermektedir. 
Dokuz Eylül Üniversitesi İktisadi ve İdari Bilimler Fakültesi Dergisi Cilt:32, Sayl:2, Yll:2017, ss. 79-107

Tablo 10. S-VAR, TY-VAR, DL-VAR'aAitDiagnostik Testler

\begin{tabular}{|c|c|c|c|}
\hline Diagnostik Testler & S-VAR(2) & $\begin{array}{c}\text { TY- } \\
\text { VAR(2) }\end{array}$ & $\begin{array}{c}\text { DL- } \\
\text { VAR(2) }\end{array}$ \\
\hline Otokorelasyon Testi & $3,74(0,44)$ & $5,07(0,27)$ & $1,62(0,80)$ \\
\cline { 2 - 4 } & $0,72(0,94)$ & $5,38(0,25)$ & $1,80(0,77)$ \\
\hline Değișen Varyans Testi & $20,43(0,67)$ & $27,19(0,29)$ & $33,29(0,29)$ \\
\hline Normallik Testi & $4,56(0,33)$ & $1,57(0,81)$ & $1,66(0,79)$ \\
\hline AR Kök Değerleri & $<0,65$ & $<0,68$ & $<0,87$ \\
\hline
\end{tabular}

\section{SONUÇ}

Turizm dünya ekonomisi içerisinde birçok ekonomik göstergeyi etkilemesinin yanı sıra en hızlı büyüyen sektörler arasındadır. 1980'li yıllardan itibaren turizmde önemli yatırımlar yapan Türkiye için de bu durum söz konusudur. Özellikle 2000 yılından sonra Türkiye turizmde dünyadaki diğer ülkelerle rekabet edebilecek konuma gelmiştir. Bu durum Türkiye'nin turizm gelirleri ve ülkeye gelen turist sayısına dair dünya sıralaması dikkate alındığında kolaylıkla görülebilmektedir. Turizm faaliyetleri ileriki dönemlerde ticari amaçla yapılan seyahatlere dönüşebilir. Bu dönüşüm ilk olarak turistik amaçla gidilen ülkeye özgü ürünlerin ithalatını yapma talebi olarak gerçekleşebilir. Benzer şekilde iş seyahati olarak başlayan seyahatlerde daha sonraki dönemlerde yakınlar ve arkadaşlarla yapılan tatil amaçlı turizm faaliyetine dönüşebilmektedir. $\mathrm{Bu}$ durumda öncelikle ticari amaçla gidilen ülkenin özelliklerden etkilenildiği söylenebilir. Türkiye’yi en çok ziyaret eden ülkeler dikkate alındığında, bu ülkelerin çoğunun aynı zamanda ülkenin en fazla ticari faaliyetler gösterdiği ülkeler içerisinde yer aldığ görülmektedir.

Bu çalışmada, Türkiye’nin elde ettiği turizm gelirleriyle dışa açıklığı arasındaki ilişki incelenmiştir. Bu amaçla 1985-2014 dönemi yıllık veri seti, Sims (1980)S-VAR, Toda-Yamamoto (1995) TY-VAR(2) ve Dolado-Lütkepohl (1996) DL-VAR modelleri ile tahmin edilmiştir. Alternatif VAR modellerinden elde edilen bulgular dışa açıklık ve turizm gelirleri arasında tek yönlü ve pozitif bir nedensellik ilişkisi olduğunu göstermektedir. Türkiye’nin dış ticareti arttıkça 


\section{H.TERZİ -A.TÜTÜNCÜ}

ülkeye gelen turist sayısının ve turizm gelirlerinin de arttı̆̆ gözlenmiştir. Turistlerin geldikleri ülkede yaptıkları döviz harcamasıyla ülkenin ihracat kalemini arttırdığı dikkate alındığında bu durumun hizmet ihracatını arttırarak ödemeler bilançosuna katkı sağladığı söylenebilir. Çalışma sonuçları, literatür çalışmalarında yer alan turizm gelirleri ile dışa açıklık arasındaki ilişkinin varlığını desteklemektedir. Farklı ülkeler için yapılan çalışmalarda tek veya çift yönlü ilişkiye rastlanmaktadır. Türkiye için yapılan çalışmalarda da bu durum geçerlidir. Dışa açıklıktan turizm gelirlerine doğru pozitif bir nedenselliğin olması, dışa açıklıkta meydan gelen değişmeye turizm gelirlerinin pozitif bir tepki vereceğini göstermektedir. Bu durumda ülkenin yabancı ülkelerle olan ticari faaliyetlerini arttırmak için iyileştirici düzenlemeler yapılmalıdır. İhracatı ve ithalatı arttırıcı düzenlemeler, ülkenin ödemeler bilançosuna katkıda bulunmasının yanı sıra, Türkiye'nin diğer ülkelerce tanınmasına yardımcı olmaktadir.

\section{KAYNAKÇA}

APERGIS, N., TANG, C. F. (2013), "Is the Energy-Led Growth Hypothesis Valid? New Evidence from a Sample of 85 Countries", Energy Economics, 38, 24-31.

BAHAR, O., BALDEMIR, E. (2008), "Uluslararas1 Ticaret ile Uluslararas1 Turizm Arasındaki Nedensellik İlişkisi: Türkiye Örneği”, Dokuz Eylül Üniversitesi Sosyal Bilimler Enstitüsü Dergisi, 10(4), 97-111.

BAHAR, O., BOZKURT, K. (2010), "Gelişmekte Olan Ülkelerde TurizmEkonomik Büyüme İlişkisi: Dinamik Panel Veri Analizi”, Anatolia: Turizm Araştırma Dergisi, 21(2), 255-265.

BULUT, E. (2000), “Türk Turizminin Dünya'daki Yeri ve Dış Ödemeler Bilançosuna Etkisi”, Gazi Üniversitesi IIIBF Dergisi, 2(3), 71-86.

DICKEY, D. A., FULLER, W. A. (1981), "Likelihood Ratio Statistics for Autoregressive Time Series with a Unit Root", Econometrica, 49(4), 10571072.

DOLADO, J. J., LUTKEPOHL, H. (1996), "Making Wald Tests Work for Cointegrated VAR Systems”, Econometric Reviews, 15(4), 369-386. 
ENDERS, W. (2015), Applied Econometric Time Series, John Wiley \& Sons.

EGELİ, H. A. (1997), "Türk Turizminin D1ş Ticaret ve Sektörler Arası Bağlantıları Açısından Değerlendirilmesi”, Ankara Üniversitesi SBF Dergisi, 52(01), 235-246.

FRY, D., SAAYMAN, A., SAAYMAN, M. (2010), "The Relationship between Tourism and Trade in South Africa", South African Journal of Economics, 78(3), 287-306.

KHAN, H., TOH, R. S., CHUA, L. (2005), "Tourism and Trade: Cointegration and Granger Causality Tests", Journal of Travel Research, 44(2), 171-176.

KULENDRAN, N., WILSON, K. (2000), "Is There a Relationship between International Trade and International Travel?" Applied Economics, 32(8), 10011009 .

LEE, C. C. (2006), "The Causality Relationship between Energy Consumption and GDP in G-11 Countries Revisited", Energy Policy, 34(9), 1086-1093.

LEE, C. G. (2012), "Tourism, Trade, and Income: Evidence from Singapore", Anatolia: An International Journal of Tourism and Hospitality Research, 23(3), 348-358.

LUZZI, F. G., FLUCKIGER, Y. (2003), "Tourism and International Trade: Introduction”, Pacific Economic Review, 8(3), 239-243.

MASSIDDA, C., MATTANA, P. (2012), "A SVECM Analysis of the Relationship between International Tourism Arrivals, GDP and Trade in Italy", Journal Travel Research, 52, 93-105.

NOWAK, J. J., SAHLI, M., CORTÉS-JIMÉNEZ, I. (2007), "Tourism, Capital Good Imports and Economic Growth: Theory and Evidence for Spain", Tourism Economics 13, 515-536.

ÖZCAN, C. C., YORGANCILAR, F. N. (2016), "Uluslararası Ticaret ve Turizm Arasında bir İlişki Var mı?”, Yönetim ve Ekonomik Araştırmalar Dergisi, 14(1), 37-48.

PHILLIPS, P. C. B., PERRON, P. (1988), “Testing for a Unit Root in Time Series Regression”, Biometrika, 75(2), 335-346. 


\section{H.TERZİ -A.TÜTÜNCÜ}

POLAT, E., TÜRKAN, S., GÜNAY, S. (2010), "Relationship between Tourism and Trade in Turkey", International Conference on Applied Economics (ICOAE), Athens, 26-28. August 591-596, http://kastoria.teikoz.gr/ icoae2/wordpress/wp-content/uploads/articles/2011/10/066.pdf, (Erişim: 04.05.2016).

SANTANA-GALLEGO, M., LEDESMA-RODRIGUEZ, F., PÉREZRODRIGUEZ, J. V. (2011), "Tourism and Trade in OECD Countries. A Dynamic Heterogeneous Panel Data Analysis", Empirical Economics, 41(2), 533-554.

SARMIDI, T., SALLEH, N. M. H. (2010), "Dynamic Inter-Relationship between Trade, Economic Growth and Tourism in Malaysia", MPRA Paper No. 21056.

SIMS, C. A. (1980), "Macroeconomics and Reality", Econometrica, 48(1), $1-48$.

SUN, G., Y. HUN, L. YU (2008), "A Study on Relationship between Foreign Openness Degree and Inbound Tourism Development in China", International Journal of Business and Management, 3(1), 62-69.

SURUGIU, C., M. R. SURUGIU (2011), "Causality between Tourism Exports and Trade Openness: Empirical Analysis for Romanian Tourism", Young Economists Journal/Revista Tineril or Economisti, 9(17), 100-110.

T. C. Kültür Bakanlığ1, Turizm Verileri, www.kultur.gov.tr/Eklenti/2140, turizmverileripdf.pdf?0, (Erişim: 18.04.2016).

TANDOĞAN, D., GENÇ, M. C. (2016), "Türkiye'de Turizm ve Ticari Açıklık Arasındaki İlişki: Toda ve Yamamoto Nedensellik Yaklaşımı", Ekonomik ve Sosyal Araştırmalar Dergisi, 12(1), 59-70.

TELATAR, O. M., TERZİ, H. (2009), "Türkiye'de Ekonomik Büyüme ve Cari İşlemler Dengesi İlişkisi”, Atatürk Üniversitesi İ̈BF Dergisi, 23(2), 119134.

TODA, H. Y., YAMAMOTO, T. (1995), "Statistical Inference in Vector Autoregressions with Possibly Integrated Processes", Journal of Econometrics, 66(1), 225-250.

WILSON, K., SHAN, J. (2001), "Causality between Trade and Tourism: Empirical Evidence from China”, Applied Economics Letters, 8, 279-283.

WOLDE-RUFAEL, Y. (2005), "Energy Demand and Economic Growth: The African Experience", Journal of Policy Modeling, 27(8), 891-903. 
WONG, K. N., TANG, T. C. (2008), "Tourism and Openness to Merchandise and Services Trade in Singapore: An Empirical Investigation", Monash University, Department of Economics, 26/08.

WORLD BANK (2014), “2014 World Development Indicators", http://elibrary. worldbank.org/doi/pdf/10.1596/978-1-4648-0163-1, (Erişim: 12.04.2016).

YILANCI, V., BOZOKLU, Ş. (2014), "Türk Sermaye Piyasasında Fiyat ve İşlem Hacmi İlişkisi: Zamanla Değişen Asimetrik Nedensellik Analizi”, Ege Akademik Bakış, 14(2), 211-220.

ZAPATA, H. O., RAMBALDI, A. N. (1997), “ Monte Carlo Evidence on Cointegration and Causation" Oxford Bulletin of Economics and Statistics, 59(2), 285-298.

ZENGIN, B. (2010), "Turizm Sektörünün Türkiye Ekonomisine Reel ve Moneter Etkileri”, Akademik Incelemeler Dergisi, 5(1), 102-126. 